\title{
Editorial: Crayons and People are not for Consumption: A Social Work Discourse on Crayola's New Box
}

\author{
Heidi Breaux ${ }^{1}$ \\ Published online: 1 August 2020 \\ (c) Springer Science+Business Media, LLC, part of Springer Nature 2020
}

\begin{abstract}
In May 2020, the Crayola Crayon Company released a new version of their crayon box that specifically focuses on skin tone. This was met with mass media attention in part due to marketing and business partnerships which touted the concept of skin tone crayons as new, although their last release of a skin tone box was in 1994. Not only was this crayon box made to promote creativity for children, it was specifically designed to foster inclusivity. The crayons designed to promote acceptance were made for a large audience of children at school and home, although anti-racism education is infrequently taught in the classroom. Crayola called the crayon box "Colors of the World", and it was printed in 3 languages. The skin hues that were created displayed new names like almond and rose. From an anti-oppressive lens set in America, both the name on the box and on the crayons caused questions for concern. While the idea of having many skin tone colors to choose from was a wonderful concept, the messaging called for scrutiny. Before giving the entire "Colors of the World" box to children or sharing about its release on social media, it is important to look more extensively into the subtle and maybe not so understated indications of White Nationalism, Colorism, and Colonization.
\end{abstract}

Keywords Children $\cdot$ Education $\cdot$ Racism $\cdot$ White supremacy $\cdot$ Parenting

On May 21st, 2020 Crayola announced a new crayon set called "Colors of the World." This crayon set was designed to represent "more than 40 global skin tones", with a focus on children of all ages, races, cultures, and ethnicities and meant to foster inclusion and acceptance (Rivera 2020). Teachers, parents, aunts, uncles, and grandparents alike, jumped to share their excitement about such a crayon box set on social media. The release of this box was also shared and touted by multiple news outlets. Similar sets have been released by other companies, and was also released by Crayola in 1994 as the "Multicultural Collection" (Elizabeth 2020). As a parent in the United States who needs to examine every educational aspect extensively because history books in this country have been made inaccurate by having history changed, and the positive influence of Black, Indigenous, and People of Color erased, I needed to look further (King 2019). The concept was great, the application left much to be desired.

Heidi Breaux

hbreaux@tulane.edu

1 Tulane University, New Orleans, LA, USA

\section{Drawing the Line Towards White Supremacy}

The crayon set with the concept of many skin tone colors is something as a white parent that I'd definitely purchase. White allies need to pay particularly close attention to educational items they are giving to their children. Even if a school is diverse, this does not necessarily mean they are teaching the students anti-racist practice (Lynch 2018). Kids in America should not view this set of multi-colored skin tone crayons as colors from all over the world. Instead I would hope they would look at the varying array of multiple crayons and identify them as colors of their classmates, their teachers, their relatives, their friends, their parent's friends, and so on. Stating that these are "Colors of the World" lends itself to the belief that the pale skin tone still in the standard box is the "original" color or "normative" color for American children. A notion that is inaccurate at best, and racist at worst.

Perhaps the title of the box was meant to reflect that America is made of up many different ethnicities and cultures that immigrated to the United States. Nonetheless this still doesn't account for the colonization of Native American and Indigenous communities who were here way 
before any white person was (Krakoff 2016). Additionally, certain racial identities in America may not have or feel ties to another culture outside of the U.S., and this assumption is steeped in White Nationalism (Amaya 2018). This concept also lends itself to deep Colorism, assuming that people of different skin tones are from varying ethnicities and cultures (Landor et al. 2013). If one kid used a different color crayon for themselves than their sibling, would that imply the sibling is from another part of the world? Even if Crayola had intended to market to a worldwide audience, their sell-out to white-washed capitalism was evident (Koechlin 2019).

\section{Skin is not for Consumption}

The other concern with the "Colors of the World" crayon set was with the names of the actual crayons. Different colored hues were identified as almond and rose tones, such as light almond, medium deep almond, extra deep almond, very light rose, and light medium rose, just to name a few (Rivera 2020). The word "light" was used to identify the shades typically more associated with white individuals, and the words "deep" for people of color. The word "light" implies purity, carefree, and safe. The word "dark" is often associated with complex, hidden, and even nefarious, overwhelming, or burdensome. The word "almond" as a descriptor for a skin color crayon is extremely problematic. For most white people who practice anti-racism it is well known not to describe children or Black, Indigenous, and People of Color by using food for their skin tone such as "chocolate" or "cocoa". This was socially acceptable for years causing a long history of trauma and de-humanization (Wilder 2010). Should we make an exception for almond? Certainly not! Almonds are consumed, eaten, digested; they are a commodity, and any referencing linking identities of color or skin tone to food or an item meant to be bought, sold, or traded, certainly evokes a traumatic connection to the history of enslavement in America (Rinehart 2016). White people have consumed, ingested, chewed up and spit out so many facets of non-white culture by acts of culture appropriation, dominance, and oppression- that these nouns for skin need to be permanently retired (Heffernan 2018). Someone's skin tone should never be compared to an object, such as rose or almond, as these are things not descriptors for people. It also just seems like a bizarre reference scientifically for a box of crayons, because while almonds do come in different tones, typically a bag of almonds is quite homogenous. It important to remember that these crayons are often used as teaching tools, so no longer teaching white kids to call their classmates "chocolate" or "cocoa" is vital, but certainly should not then be replaced with "rose", "almond," or "golden."

\section{The World Speaks in More than Three Languages}

I look forward to the day where every kid has a color in the crayon box that they can identify as representing their skin tone. It would be wonderful if all of their new hues were just called "skin." This not meant to equalize, but is also questioning the need to describe the tone in a method that is easily relatable in American society and comprehended by whites. After all, movements meant to implore sameness while recognizing diversity such as "All Lives Matters," are not representative of anti-racist, anti-oppressive practice; they are the opposite (Carney 2016). Using color descriptors that all have positive connotations, that are not objects, or food is needed. Crayola said that the formulation of their colors underwent rigorous testing through a partnership with MOB Beauty and Crayola's Research and Development Marketing Teams, however mention of the labels and names was left out. The announcement that the set would first be sold exclusively through pre-order by Walmart, seemed apropos (Goldstein 2020). The crayons have been produced in English, Spanish, and French (Rivera 2020). If Crayola wanted to focus on their worldwide audience or provide a multi-national appearance, then perhaps they should consider printing "Colors of the World" in more than 3 languages (Rivera 2020).

\section{Social Workers Should Question Labels}

Social workers are bound by the NASW Code of Ethics to comprehensive understand complex issues around race, ethnicity, and identity (National Association of Social Workers (NASW) 2020). As a profession that often serves clients through oral dialogue, even a novice social worker learns very quickly that what your intended message, what you said, and how it was heard-can be all separate things. Typically how your message was received, being the most impactful. Social workers strive to not simply attain cultural sensitivity and competency, but to be centered in cultural humility as well (Danso 2018). Social workers should question-Why has the authority to name skin color been given to Crayola in the first place? Furthermore-Are they doing a good job with it?

Most social workers know that we do not use our language to speak for others, but rather use our social work skills set to uplift their own voice. The identity, voice, story, history, and culture of each individual is their own, true, and important (Boehm \& Staples 2002). Given the current climate of racism in our country we need to question every piece of educational material put in the 
classroom and given to children by critically looking at it through an anti-oppressive and anti-racist lens. With this crayon box, it is vital that social workers continue to question if real sustainable change has been obtained or are we once again seeing elements of the same coded racism repackaged.

\section{References}

Amaya, H. (2018). White nationalism and publicness in the United States. Javnost-The Public, 25(4), 365-378. https://doi. org/10.1080/13183222.2018.1463348.

Boehm, A., \& Staples, L. (2002). The functions of the social worker in empowering: The voices of consumers and professionals. Social Work, 47(4), 449-460. www.jstor.org/stable/23718753

Carney, N. (2016). All lives matter, but so does race: Black lives matter and the evolving role of social media. Humanity \& Society. https ://doi.org/10.1177/0160597616643868.

Danso, R. (2018). Cultural competence and cultural humility: A critical reflection on key cultural diversity concepts. Journal of Social Work, 18(4), 410-430. https://doi.org/10.1177/146801731665434 1 .

Elizabeth, D. (2020). Crayola's new crayons are meant to represent the skin tones of the world. Teen Vogue.https://www.teenvogue.com/ story/crayola-crayons-colors-of-world-skin-tones

Goldstein, J. (2020). Crayola launches box of crayons with diverse skin tones to 'Advance inclusion in creativity'. People.https:// people.com/human-interest/crayola-launches-crayon-box-color s-of-world-skin-tone-diversity/

Heffernan, N. (2018). "As usual, I'll have to take an IOU”: W. E. B. Du Bois, the gift of Black music and the cultural politics of obligation. Journal of American Studies, 52(4), 1095-1121. https://doi. org/10.1017/S0021875817000883.

King, C. (2019). American students are not learning the truth about race. Time.https://time.com/5642773/american-students-taugh t-race/
Koechlin, T. (2019). Whitewashing capitalism: Mainstream economics' resounding silence on race and racism. Review of Radical Political Economics, 51(4), 562-571. https://doi.org/10.1177/0486613419 873229.

Krakoff, S. (2016). They were here first: American Indian tribes, race, and the constitutional minimum. Stanford Law Review. https:// doi.org/10.2139/ssrn.2746166.

Landor, A., Simons, L., Simons, R., Brody, G., Bryant, C., Gibbons, F., et al. (2013). Exploring the impact of skin tone on family dynamics and race-related outcomes. Journal of Family Psychology: JFP: Journal of the Division of Family Psychology of the American Psychological Association (Division 43), 27(5), 817-826. https://doi.org/10.1037/a0033883.

Lynch, M. (2018). The hidden nature of whiteness in education: Creating active allies in white teachers. Journal of Educational Supervision. https://doi.org/10.31045/jes.1.1.2.

National Association of Social Workers (NASW). (2020). The Code of Ethics.https://www.socialworkers.org/about/ethics/code-of-ethics/ code-of-ethics-english

Rinehart, N. (2016). The man that was a thing: Reconsidering human commodification in slavery. Journal of Social History, 50(1), 28-50. https://doi.org/10.1093/jsh/shv129.

Rivera, J. (2020). Crayola launches box of crayons with diverse skin tones. USA Today.https://www.usatoday.com/story/money /2020/05/21/crayola-launches-different-skin-tone-crayons/52405 $02002 /$

Wilder, J. (2010). Revisiting "Color names and color notions": A contemporary examination of the language and attitudes of skin color among young Black women. Journal of Black Studies, 41(1), 184-206. www.jstor.org/stable/25704101

Publisher's Note Springer Nature remains neutral with regard to jurisdictional claims in published maps and institutional affiliations. 